\title{
Herbal Medicines Used in the Treatment of Chronic Insomnia and How They Influence Sleep Patterns: A Review
}

\author{
Thomas Harris* and Jane Nikles \\ The University of Queensland Centre for Clinical Research, The University of Queensland, Australia
}

Submission: April 08, 2018; Published: April 30, 2018

*Corresponding author: Thomas Harris, The University of Queensland Centre for Clinical Research, The University of Queensland, Brisbane, Australia, Email: t.harris@uq.edu.au

\begin{abstract}
This review will explore the main herbal medicines used to treat chronic insomnia including valerian, hops, chamomile, passionflower and kava and their impact on sleep parameters. There is clear evidence from the literature that some herbal medicines have been shown to improve sleep latency, reduce wake time after sleep onset and increase total sleep time. Combinations, of herbal medicines have been explored in the treatment of insomnia as well, with mixtures of valerian, passionflower and hops being as effective as medications in the treatment of insomnia. Key considerations for the practice of herbal medicines are important to take into account when designing studies to effectively identify their benefits, and a minimum dosages and duration of treatment should be reflected in study design. The review will conclude with an exploration into the concept of personalised medicines and examine two key methodologies applied to this field - the $\mathrm{N}$-of- 1 clinical trials and single caseexperimental designs.
\end{abstract}

Keywords : Herbal medicine; Chronic insomnia; Valerian; Kava; Hops; Passionflower; Chamomile; N-of-1 trials; Single case-experimental designs Aim : The aim of this review is to examine the current clinical evidence for improvements in sleep parameters from single and combination herbal medicines in insomnia.

\section{Introduction}

Sleep is considered an active biological process and fundamentally required to promote health and well-being [1].

Insomnia is defined as a sleep-wake disorder; characterised by difficulty in initiating sleep, staying asleep and/or by waking early in the morning and being unable to get back to sleep [2,3]. The latest population-based survey by Adams in 2016 reported the prevalence of sleep problems in Australian adults to be: diagnosed sleep apnoea $8 \%$, significant insomnia $20 \%$ and restless legs $18 \%$ of adults. It is a condition that affects people worldwide with increased rates seen in older people, females and those with medical or psychiatric illness [4].

Despite its high prevalence, insomnia often goes unrecognised and remains untreated [5]. Insomnia also negatively affects health and well-being, with daytime impairment of cognition, mood, or performance that impacts not only on the person, but also family, friends, co-workers and caretakers [4]. Furthermore, people experiencing insomnia are also more likely to visit hospitals and physicians, have greater absenteeism, are more susceptible to traffic accidents and have more fatal road accidents [6,7]. Studies have also shown that insomnia is linked to a range of chronic diseases, including an increased risk of obesity [8], type-2 diabetes, heart disease [9], disturbances in mood, concentration and memory and an increased risk of mortality. The economic cost of treating obstructive sleep apnea, primary insomnia and restless legs combined approached $\$ 818$ million in Australia? in 2010 [1].

There are a range of treatment approaches for insomnia, which have been researched, and can be separated into three key areas:

i. Non-pharmacological approaches: cognitive behavioural therapy for insomnia (CBT-I)and sleep hygiene [10]

ii. Pharmacological interventions including: short-term benzodiazepines [11] 
iii. Complementary and alternative medicines: ingestive (such as supplements and herbal medicine) and manual therapies (including massage, kinesiology).

CBT-I is the gold standard for the treatment of insomnia with multiple randomised trials demonstrating that $70-80 \%$ of patients benefit from this therapy [12-14]. Approximately $40 \%$ of patients achieve remission from insomnia after CBT-I therapy. Although highly effective, CBT-I remains underutilised as a primary therapy for insomnia [15].

Benzodiazepines are a common pharmacological agent used in the treatment of insomnia. They are an allosteric modulator of the $y$-aminobutyric acid (GABAA) receptor complex, commonly referred to as the benzodiazepine receptor $[16,17]$. These agents enhance sleep-promoting effects of homeostatic sleep-drive and decrease arousal by binding to the pocket created by the $\alpha$ and $\gamma$ subunits and induce a conformational change in the GABA-A receptor [18]. Benzodiazepines bind to the pocket created by $\alpha$ and $\gamma$ subunits and induce a conformational change in the GABA-A receptor. This alteration, in turn, induces a conformational change in the GABA-A receptor's chloride channel that hyperpolarizes the cell and accounts for GABA's inhibitory effect throughout the central nervous system [19]. A meta-analysis showed that the short-term use of benzodiazepines (range 4-35 days) produced reliable short-term improvements in sleep-onset latency (effect size $=0.56$ ), number of awakenings (effect size $=0.65$ ), total sleep time (effect size $=0.71$ ) and sleep quality (effect size $=0.62$ ) [20]. A few long-term trials have shown that benzodiazepines have continued efficacy and safety over a time period of 3-12 months; most of these studies have been conducted in primary insomnia without comorbid psychiatric illness [21-23]. However, withdrawing from benzodiazepines has been reported to produce an initial syndrome of insomnia

Table 1: Summary of sleep outcomes in insomnia and the dosage and duration of herbal medicines.

\begin{tabular}{|c|c|c|c|c|c|c|}
\hline $\begin{array}{l}\text { Author } \\
\text { (Year) }\end{array}$ & Study Design & Study Population & $\begin{array}{c}\text { Dosage of } \\
\text { Herbal Medicine } \\
\text { Intervention }\end{array}$ & $\begin{array}{l}\text { Duration of } \\
\text { Treatment }\end{array}$ & $\begin{array}{l}\text { Sleep Outcome } \\
\text { Measures }\end{array}$ & $\begin{array}{c}\text { Changes In Sleep } \\
\text { Measures }\end{array}$ \\
\hline $\begin{array}{l}\text { Balderer et } \\
\text { al, } 1985\end{array}$ & Placebo pilot trial & $\begin{array}{l}18 \text { adults with no } \\
\text { major sleep related } \\
\text { issues; age ranged } \\
\text { from } 21-26\end{array}$ & Valerian - 900mg & Five nights & $\begin{array}{c}\text { Self-rated } \\
\text { questionnaire and } \\
\text { polygraphicsleep } \\
\text { EEG. }\end{array}$ & $\begin{array}{l}\text { Reduced sleep } \\
\text { latency, increase } \\
\text { total sleep time and } \\
\text { reduce wake time } \\
\text { after sleep onset. }\end{array}$ \\
\hline $\begin{array}{l}\text { Coxeter et } \\
\text { al (2003) }\end{array}$ & $\begin{array}{l}\text { Multiple n-of-1 } \\
\text { randomised, double } \\
\text { blind, placebo- } \\
\text { controlled crossover } \\
\text { trials. }\end{array}$ & $\begin{array}{l}24 \text { adults over the age } \\
\text { of } 18 \text { with a new or } \\
\text { existing symptoms of } \\
\text { chronic insomnia. }\end{array}$ & $\begin{array}{l}\text { Valerian - two tablets } \\
30 \text { minutes before } \\
\text { bed. } 225 \mathrm{mg}(1000 \mathrm{mg} \\
\text { dry root rhizome } \\
\text { - standardised to } \\
\text { Valerenic acids. } 2.94 \\
\text { mg total. }\end{array}$ & Three weeks. & Sleep diary. & $\begin{array}{l}\text { No improvements } \\
\text { in sleep outcomes } \\
\text { as measured }\end{array}$ \\
\hline $\begin{array}{l}\text { Donath et } \\
\text { al (2000) }\end{array}$ & $\begin{array}{l}\text { Randomised double } \\
\text { blind, placebo- } \\
\text { controlled crossover } \\
\text { trial. }\end{array}$ & $\begin{array}{l}16 \text { adults over the age } \\
\text { of } 22 \text { years old with } \\
\text { psychophysiological } \\
\text { insomnia }\end{array}$ & $\begin{array}{l}\text { Valerian (Valerian } \\
\text { officinalis) - two } \\
\text { tablets } 60 \text { minutes } \\
\text { before bed. } 300 \mathrm{mg} \\
\text { root extract ( } 5: 1 \\
\text { ratio). }\end{array}$ & $\begin{array}{l}\text { Two-week } \\
\text { treatment. }\end{array}$ & $\begin{array}{l}\text { Polysomnographic } \\
\text { recordings. }\end{array}$ & $\begin{array}{c}\text { Reduced sleep } \\
\text { latency, slow wave } \\
\text { sleep latency }\end{array}$ \\
\hline
\end{tabular}

followed by persistent anxiety [24]. In addition, there are significant concerns regarding dependency issues and adverse events, which are common with benzodiazepines and include headache, nightmares, daytime fatigue, nausea, confusion and falls [18]. Concerns about the use of pharmacological agents may lead to suffers of insomnia to seek out alternative treatments that have fewer withdrawal issues and adverse events, such as complementary and alternative therapies.

Complementary and alternative medicines are commonly used in Australia for insomnia, with herbal medicines being most frequently sought after [25]. They are generally considered safe and effective with very few reported adverse events $[7,13]$. Traditional evidence supports the use of numerous herbal medicines for insomnia including withania (Withania somnifera), hops (Humulus lupulus), lemon balm (Melissa officinalis), German chamomile (Matricaria recutita), valerian (Valerian officinalis), kava (Piper methysticum), ziziphus (Ziziphusjujuba) and many more, as described by Romero et al. [26]. A number of systematic reviews have been undertaken to investigate the evidence for herbal medicines in the treatment of insomnia [2527] with empirical evidence supporting the traditional evidence for the use of valerian, chamomile, kava, hops and wuling [26].

\section{Valerian (Valerian officinalis)}

Previous research has reported that the effects of Valerian in treating insomnia are quite variable, with this variation likely to be due to the different dosages and durations of treatment utilised (results summarised in Table 1). To date no study has investigated the traditional dosage of Valerian (dose range 2000$3500 \mathrm{mg}$ ) in a population of people suffering from insomnia, currently all dosages reported fall well below the recommended traditional dose of the herb (Table 1). 


\begin{tabular}{|c|c|c|c|c|c|c|}
\hline $\begin{array}{l}\text { Oxaman et } \\
\text { al (2007) }\end{array}$ & $\begin{array}{l}\text { Randomised, double- } \\
\text { blind, placebo- } \\
\text { controlled parallel- } \\
\text { group trial. }\end{array}$ & $\begin{array}{l}434 \text { adults aged } 18-75 \\
\text { years of old suffering } \\
\text { from insomnia for } \\
\text { more than one month. }\end{array}$ & $\begin{array}{l}\text { Valerian - three } \\
\text { tablets } 60 \text { minutes } \\
\text { before bed. } 200 \mathrm{mg} \\
\text { extract (equivalent to } \\
1200 \mathrm{mg} \text { dried root). }\end{array}$ & $\begin{array}{l}\text { Two-weeks } \\
\text { treatment. }\end{array}$ & Sleep diary. & $\begin{array}{l}\text { No improvements } \\
\text { in sleep quality } \\
\text { with a trend } \\
\text { in the valerian } \\
\text { group for less } \\
\text { night awakening } \\
\text { and greater sleep } \\
\text { duration }\end{array}$ \\
\hline $\begin{array}{l}\text { Diaper et } \\
\text { al (2004) }\end{array}$ & $\begin{array}{l}\text { Randomised, double- } \\
\text { blind, placebo- } \\
\text { controlled cross-over } \\
\text { study }\end{array}$ & $\begin{array}{l}16 \text { participants } \\
\text { aged } 50-64 \text { years of } \\
\text { age, that had sleep } \\
\text { disturbances }\end{array}$ & $\begin{array}{c}\text { Valerian two dosages } \\
\text { were given } 300 \text { and } \\
600 \mathrm{mg} \text {. }\end{array}$ & $\begin{array}{c}\text { One-day } \\
\text { treatment } \\
\text { with washout } \\
\text { periods } \\
\text { between } \\
\text { doses. }\end{array}$ & $\begin{array}{c}\text { Standardised sleep } \\
\text { EEG. }\end{array}$ & $\begin{array}{c}\text { Valerian provided } \\
\text { no benefits on sleep } \\
\text { outcomes. }\end{array}$ \\
\hline $\begin{array}{l}\text { Jacobs et } \\
\text { al-2005 }\end{array}$ & $\begin{array}{c}\text { A randomised, } \\
\text { placebo-controlled } \\
\text { trial }\end{array}$ & 391 participants & $\begin{array}{l}\text { Valerian }(3.2 \mathrm{mg} \\
\text { valerenc acid) } \\
\text { and kave (100 mg } \\
\text { kavalactones) }\end{array}$ & Four weeks & $\begin{array}{l}\text { Insomnia severity } \\
\text { index (ISI). }\end{array}$ & $\begin{array}{l}\text { No benefit of } \\
\text { kava and valerian } \\
\text { compared to } \\
\text { placebo as } \\
\text { measured by ISI. }\end{array}$ \\
\hline $\begin{array}{l}\text { Ziegler et } \\
\text { al (2002) }\end{array}$ & $\begin{array}{c}\text { Multicentre, } \\
\text { randomised, } \\
\text { double-blind, active- } \\
\text { controlled parallel- } \\
\text { group trial }\end{array}$ & $\begin{array}{l}202 \text { adults aged } 18-73 \\
\text { years of age with non- } \\
\text { organic insomnia. }\end{array}$ & $\begin{array}{l}\text { Valerian }-600 \mathrm{mg} \\
\text { (ethanol extract) two } \\
\text { tablets per day, } 60 \\
\text { minutes before bed. } \\
\text { Oxazepam - } 10 \mathrm{mg} / \\
\text { day. }\end{array}$ & $\begin{array}{l}\text { Six-weeks } \\
\text { treatment. }\end{array}$ & $\begin{array}{c}\text { Sleep } \\
\text { questionnaire B. }\end{array}$ & $\begin{array}{c}\text { Valerian extract } \\
\text { was as efficacious } \\
\text { as oxazepam in } \\
\text { improving sleep } \\
\text { quality. }\end{array}$ \\
\hline $\begin{array}{l}\text { Taavoni et } \\
\text { al (2011) }\end{array}$ & $\begin{array}{l}\text { Randomised, triple- } \\
\text { blind controlled } \\
\text { clinical trial }\end{array}$ & $\begin{array}{l}100 \text { postmenopausal } \\
\text { women aged } 50-60 \\
\text { years old experiencing } \\
\text { insomnia. }\end{array}$ & $\begin{array}{l}\text { Valerian - } 530 \mathrm{mg} \text { of } \\
\text { concentrated extract. }\end{array}$ & Four weeks & $\begin{array}{l}\text { Pittsburgh Sleep } \\
\text { Quality Index. }\end{array}$ & $\begin{array}{l}\text { Sleep quality } \\
\text { improved in the } \\
\text { valerian group. }\end{array}$ \\
\hline $\begin{array}{l}\text { Lehrl } \\
-2004\end{array}$ & $\begin{array}{c}\text { Multicentre, } \\
\text { randomised placebo- } \\
\text { controlled double- } \\
\text { blind clinical trial }\end{array}$ & $\begin{array}{l}61 \text { participants with } \\
\text { generalised anxiety } \\
\text { disorder with sleep } \\
\text { issues; with an age } \\
\text { range } 24-72 \text { year of } \\
\text { age. }\end{array}$ & $\begin{array}{c}\text { Kava - } 200 \text { mg daily } \\
\text { dose. }\end{array}$ & Four weeks. & $\begin{array}{c}\text { Sleep } \\
\text { questionnaire B. }\end{array}$ & $\begin{array}{l}\text { Quality of sleep } \\
\text { and recuperative } \\
\text { effect after sleep } \\
\text { improved after kava } \\
\text { administration. }\end{array}$ \\
\hline $\begin{array}{l}\text { Adib- } \\
\text { Hajbahery } \\
-2017\end{array}$ & $\begin{array}{l}\text { Single blind } \\
\text { randomised } \\
\text { controlled trial }\end{array}$ & $\begin{array}{c}196 \text { elderly } \\
\text { participants with and } \\
\text { age of } 60 \text { or more } \\
\text { included into the } \\
\text { study. }\end{array}$ & $\begin{array}{c}\text { Chamomile }-400 \mathrm{mg} \\
\text { per day. }\end{array}$ & Four weeks. & $\begin{array}{l}\text { Pittsburgh Sleep } \\
\text { Quality Index. }\end{array}$ & $\begin{array}{l}\text { Sleep quality } \\
\text { significantly } \\
\text { improved. }\end{array}$ \\
\hline $\begin{array}{c}\text { Zick et al } \\
-2011\end{array}$ & $\begin{array}{l}\text { Randomised placebo } \\
\text { controlled pilot study. }\end{array}$ & $\begin{array}{l}34 \text { participants with } \\
\text { an age range of } 18-65 \\
\text { years, diagnosed with } \\
\text { primary insomnia } \\
\text { (less than } 6 \text { months). }\end{array}$ & $\begin{array}{c}\text { Chamomile }-270 \mathrm{mg} \\
\text { per day. }\end{array}$ & Four weeks. & $\begin{array}{l}\text { Sleep diary } \\
\text { measures. }\end{array}$ & $\begin{array}{c}\text { No significant } \\
\text { change in total } \\
\text { sleep time (TST), } \\
\text { sleep efficiency, } \\
\text { sleep latency, wake } \\
\text { after sleep onset } \\
\text { (WASO), sleep } \\
\text { quality, and number } \\
\text { of awakenings }\end{array}$ \\
\hline $\begin{array}{l}\text { Taibi et al } \\
\text { (2009) }\end{array}$ & $\begin{array}{l}\text { Randomised clinical } \\
\text { trial }\end{array}$ & $\begin{array}{l}16 \text { older women aged } \\
61-77 \text { years of age }\end{array}$ & $\begin{array}{l}\text { Valerian (Valerian } \\
\text { officinalis) - } 300 \mathrm{mg} \\
\text { concentrated valerian } \\
\text { extract } 30 \text { minutes } \\
\text { before bed. }\end{array}$ & $\begin{array}{l}\text { One day or } \\
\text { Two weeks }\end{array}$ & $\begin{array}{c}\text { Self-reported } \\
\text { measures and } \\
\text { polysomnography. }\end{array}$ & $\begin{array}{c}\text { No significant } \\
\text { difference between } \\
\text { valerian and } \\
\text { placebo for any } \\
\text { sleep outcome } \\
\text { measures including } \\
\text { sleep latency, wake } \\
\text { after sleep onset, } \\
\text { sleep efficiency and } \\
\text { self-rated sleep } \\
\text { quality. }\end{array}$ \\
\hline
\end{tabular}




\begin{tabular}{|c|c|c|c|c|c|c|}
\hline $\begin{array}{l}\text { Koetter et } \\
\text { al (2007) }\end{array}$ & $\begin{array}{l}\text { Randomised double } \\
\text { blind, placebo- } \\
\text { controlled study. }\end{array}$ & $\begin{array}{l}30 \text { adults age ranging } \\
\text { from } 24-48 \text { years of } \\
\text { age with non-organic } \\
\text { insomnia. }\end{array}$ & $\begin{array}{l}\text { Valerian single dose } \\
500 \mathrm{mg} \text { Valerian } \\
(500 \mathrm{mg}) \text { and Hops } \\
(150 \mathrm{mg}) \text { combination. }\end{array}$ & $\begin{array}{l}\text { Four-weeks } \\
\text { treatment. }\end{array}$ & $\begin{array}{l}\text { Objective sleep } \\
\text { parameters } \\
\text { were registered } \\
\text { by means of a } \\
\text { transportable } \\
\text { home recorder } \\
\text { system }\end{array}$ & $\begin{array}{l}\text { Fixed valerian } \\
\text { hops combination } \\
\text { significantly } \\
\text { reduced sleep } \\
\text { latency and } \\
\text { improved slow } \\
\text { wave sleep }\end{array}$ \\
\hline $\begin{array}{l}\text { Morin et al } \\
\quad(2005)\end{array}$ & $\begin{array}{l}\text { Multicenter, } \\
\text { randomized, } \\
\text { placebo-controlled, } \\
\text { parallel-group study } \\
\text { conducted in } 9 \text { sleep } \\
\text { disorders centers } \\
\text { throughout the } \\
\text { United States }\end{array}$ & $\begin{array}{l}184 \text { adults with mild } \\
\text { insomnia. }\end{array}$ & $\begin{array}{c}\text { Valerian }(187 \mathrm{mg}) \\
\text { and Hops }(41.8 \mathrm{mg}) \\
\text { combinations; } \\
\text { Diphenhydramine } \\
(25 \mathrm{mg}) .\end{array}$ & $\begin{array}{l}\text { Four-weeks } \\
\text { treatment. }\end{array}$ & $\begin{array}{l}\text { Daily diaries and } \\
\text { polysomnography. }\end{array}$ & $\begin{array}{l}\text { There was a trend } \\
\text { for a reduction } \\
\text { in sleep latency } \\
\text { for valerian and } \\
\text { hops combination } \\
\text { compared to } \\
\text { placebo; this group } \\
\text { also rated lower } \\
\text { relative to controls } \\
\text { in the ISI and } \\
\text { quality of life was } \\
\text { improve compared } \\
\text { to controls }\end{array}$ \\
\hline $\begin{array}{l}\text { Maroo et } \\
\text { al (2012) }\end{array}$ & $\begin{array}{l}\text { Study was designed } \\
\text { as a prospective, } \\
\text { parallel group, } \\
\text { double-blind, } \\
\text { randomized } \\
\text { controlled trial }\end{array}$ & $\begin{array}{l}39 \text { participants } \\
\text { were allocated to } \\
\text { the Zolpidem and } \\
\text { polyherbal groups. }\end{array}$ & $\begin{array}{l}\text { Valerian: 300mg; } \\
\text { Passionflower: } \\
\text { 80mg; Hops: } 30 \mathrm{mg} \text {; } \\
\text { Zolpidem: } 10 \mathrm{mg}\end{array}$ & $\begin{array}{l}\text { Two weeks } \\
\text { treatment } \\
\text { period } \\
\text { for both } \\
\text { polyherbal } \\
\text { and } \\
\text { Zolpidem. }\end{array}$ & $\begin{array}{l}\text { Sleep diary, Quality } \\
\text { of life and daytime } \\
\text { sleepiness was } \\
\text { evaluated by } \\
\text { insomnia severity } \\
\text { index and Epworth } \\
\text { sleepiness score. }\end{array}$ & $\begin{array}{c}\text { Significant } \\
\text { improvements in } \\
\text { TST, sleep latency, } \\
\text { WASO and ISI } \\
\text { scores. }\end{array}$ \\
\hline $\begin{array}{l}\text { Wheatley } \\
\text { (2001) }\end{array}$ & $\begin{array}{c}\text { Cross over design } \\
\text { pilot study } \\
\text { comparing kava and } \\
\text { valerian }\end{array}$ & $\begin{array}{l}24 \text { patients initially } \\
\text { received kava; } 6 \\
\text { participants dropped } \\
\text { out and the remaining } \\
19 \text { received valerian. }\end{array}$ & $\begin{array}{c}\text { Kava: } 120 \mathrm{mg} \text {; Valerian } \\
\text { 600mg. Number of } \\
\text { tabs }\end{array}$ & $\begin{array}{l}\text { Kava and } \\
\text { valerian was } \\
\text { treated for six } \\
\text { weeks with } \\
\text { a two-week } \\
\text { washout } \\
\text { period } \\
\text { between each } \\
\text { herb. }\end{array}$ & $\begin{array}{c}\text { Sleep } \\
\text { questionnaire. }\end{array}$ & $\begin{array}{c}\text { Total insomnia } \\
\text { score, which } \\
\text { significantly decline } \\
\text { after both kava and } \\
\text { valerian treatments. }\end{array}$ \\
\hline
\end{tabular}

The table reports single herbal medicines including valerian, kava, chamomile and different herbal medicine combinations.

Valerian has been reported to be beneficial in the treatment of mild to moderate insomnia [28]. In healthy participants valerian has been shown to reduce sleep latency (valerian group 14.8 minutes versus control 20.5 minutes), increase total sleep time (valerian group 417 minutes versus control group 402 minutes) and reduce the wake time after sleep onset (valerian group 19 minutes versus control 36 minutes); effects that occurred using high dosages in disease free individuals (dose: 900mg and duration: 5 days) [29].

Valerian has been reported to reduce subjective sleep latency (45minutes in the valerian group versus 60 minutes in control group) and reduce slow wave sleep latency (13.5 minutes in valerian group versus 21.3 minutes in control group) at a dose of $300 \mathrm{mg}$ per day for two weeks [30]. In contrast to this, other studies have found that valerian does not improve sleep quality with comparable improvements between valerian treatment and controls $29 \%$ improvement in valerian group versus $21 \%$ in placebo group). There was a trend towards the valerian group for less night wakening and greater sleep duration at a dose of $200 \mathrm{mg}$ per day for two weeks [31].

Our previous N-of-1 trial comparing valerian and placebo showed that the response of participants to valerian was not significant compared to controls, as shown by the combined proportion of treatment success in the valerian group, including: latency to sleep onset (0.43), number of night wakenings (0.35), total sleep time (0.35), sleep quality $(0.49)$ and post-slumber refreshment (0.40) [32]. A combined proportion of 0.43 in latency of sleep onset, for example implies that on average valerian would successfully reduce latency to sleep onset in 43 pairs out of 100 , with the placebo expected to be more successful with 57 pairs out of 100 .

Randomised controlled trials have investigated the acute effects (one day) of valerian at a dose of $300 \mathrm{mg}$ and $600 \mathrm{mg}$ compared to placebo, and showed that valerian is ineffective at improving any sleep electroencephalogram (EEG), mood or psychometric measure [33]. Taibi [34] also reported no difference in a range of sleep measures, including sleep latency, wake after sleep onset and sleep rated sleep quality, between single dosevalerian $(600 \mathrm{mg})$, two weeks valerian treatment or placebo groups. When the study compared each treatment to its baseline in separate comparisons, the sleep outcome measure, wake after sleep onset significantly increased after two weeks in the valerian treatment group $(17.7+25.6)$ but not in the placebo group $(6.8+26.4)$ [34]. This result is likely due to the rare paradoxical effect of valerian, where it produces stimulation as opposed to sedation [35]. 
Ziegler [36] published the longest trial of valerian, administering the herb over asix-week period (dose $600 \mathrm{mg}$ ). They demonstrated that it produced similar results to oxazepam (short to intermediate-acting benzodiazepine), with both agents improving sleep quality from baseline $(\mathrm{P}<0.01)$. Participants in the study also reported their respective treatments to be very good, with higher levels of satisfaction in the valerian group $(82.8 \%$ valerian group, $73.4 \%$ in the oxazepam group) [36]. The study also found similar results for other parameters for valerian and oxazepam, including: feeling of refreshment after sleep, psychic stability in the evening, psychic exhaustion in the evening, psychosomatic symptoms in the sleep phase, dream recall, and duration of sleep [36]. This study aligns well to the prescribing durations typically used by herbal medicine clinicians $[30,37,38]$, which are based on the duration of time a disease is present in an individual. For the first year a disease is present it is expected that three months of treatment using herbal medicines are required, with an additional month needed for each year above and beyond the initial year [37].

Valerian was reported to improve sleep quality in postmenopausal women with insomnia (dose: $600 \mathrm{mg}$ and duration: 4 weeks) [39]. The study showed a significant difference in the mean sleep scores (as measured by the Pittsburgh Sleep Quality Index [39] between the valerian $(3.8+1.7)$ and placebo $(1.7+1.3)$ groups. Thirty percent of participants in the valerian group and $4 \%$ of participants in the placebo group reported improvements in sleep quality [39].

\section{Kava (Piper methysticum)}

Kava has long been used in the South Pacific islands to reduce stress and anxiety and induce relaxation [40]. Kava has been reported to interact with the GABAA receptor, which is the main target for hypnotic agents that induce sleep [41,42]. Kava has been reported traditionally to have rapid onset and minimal morning after-effects $[27,43]$. One clinical trial has examined the effects of kava in participants who presented with sleep disturbance and co-morbid generalised anxiety disorder (dose: 200mg; duration: four weeks) [44]. The study showed that the score differences between baseline and end of treatment were statistically significant in the kava group for sleep quality ( 0.6 for kava and 0.36 for placebo; p-value 0.007 ) and recuperative effect after sleep ( 0.80 for kava and 0.64 for placebo; p-value 0.018 ). Further trials are required to support this study and confirm kava's effectiveness in treating chronic insomnia.

\section{Chamomile (Matricariarecutita)}

Chamomile has traditionally been used for sleep related disorders. Constituents of chamomile (apigenin and flavonoids) have been reported to bind to the benzodiazepine receptors in the brain and promote a tranquilizing effect, making them effective in insomnia $[27,45]$. Chamomile significantly improved sleep quality as measured by the Pittsburgh Sleep Quality Index (400mg; 4 week trial) in older patients with insomnia compared to controls [46]. In contrast to this, chamomile was reported to have no effect on a range of sleep parameters including sleep onset latency, wake after sleep onset time, sleep duration, nocturnal awakening, day time functioning, sleep quality and efficacy (dosage of chamomile 270mg; treatment duration 4 weeks) [47]. The dosage was 33\% lower compared to the study conducted by Adib-Hajbaghery [46] which could explain the difference in results obtained.

\section{Combinations of herbs}

The practice of herbal medicine typically involves combining herbs together to treat the underlying cause of insomnia and the associated symptoms. There are limited studies that have investigated the effects of different herbal combinations on chronic insomnia. A review by Salter [48] reported that valerian on its own or in combination with hops was associated with improvements in sleep latency and quality of sleep [48]. There are two randomised controlled trials (RCTs) that have examined the combination of valerian and hops in the treatment of insomnia $[49,50]$. Koetter et al. [50] reported that sleep latency (time to fall asleep) in the valerian/hops combination was more significantly reduced at end of the four-week trial (12 minutes) compared to valerian only (23.8 minutes) and placebo (69.7 minutes) groups ( $p$ value). Morin et al. [49] also reported an improvement in sleep latency with a valerian/hops combination from baseline to the end of the trial (baseline 35 minutes and 25 minutes at end of trial) compared to placebo (baseline 27 minutes and 24 minutes at end of trial) and diphenhydramine (baseline 25 minutes and 20 minutes at end of trial) groups nearly reached significance ( $\mathrm{p}$ value $=0.079$ ).

One trial has examined the effects of a herbal combination including valerian, passionflower and hops, reporting that it was as effective in treating primary insomniaas zolpidem (hypnotic agent used in insomnia) [51]. Sleep latency significantly improved from baseline for both groups in a similar way (sleep latency at end of study for valerian: 23.6 minutes and zolpidem: 26.4 minutes). A cross over study administering kava for six weeks (dose $120 \mathrm{mg}$ ), followed by a two-week washout period and then administration of valerian for six weeks $(600 \mathrm{mg}$ ) showed a significant reduction in mean insomnia severity in both the kava and valerian treatments from baseline; with baseline SOL being 138 minutes? falling to 107.1 minutes after kava treatment and a further to 83.1 minutes after valerian treatment [52,53]. Jacobs [54] conducted an internet-based randomised placebo-controlled study comparing valerian (dose: $600 \mathrm{mg}$ ) and kava (dose: $120 \mathrm{mg}$ ) to placebo for anxiety and insomnia over a four-week duration. The insomnia severity index (ISI) [54] was used in this study to measure differences between placebo, kava and valerian interventions. The ISI for each group was similar at four weeks from baseline: placebo -8.3 , kava -8.1 and valerian -7.9 , indicating no improvement in insomnia in any of the interventions [54].

\section{Discussion}

Currently there is some evidence to support the use of herbal medicines for chronic insomnia, although further clinical evidence is required. Valerian appears to have the most evidence 
to support its use in the treatment of chronic insomnia. The dosage of valerian used in studies to date for a mono preparation is well below the recommended therapeutic dosage range (2000$3500 \mathrm{mg} /$ day) (37). Even at lower doses valerian appears to have an effect on sleep induction and sleep quality. This question remains that if the therapeutic dose of valerian was lifted to the minimum therapeutic range, what outcome would it produce on sleep indices in people with insomnia?

Other herbs and their constituents could be just as important in promoting sleep induction and improving sleep efficacy. Kava and chamomile appear to have some initial evidence for improving sleep outcomes in people with insomnia [46,55]; effects that are mediated via the GABAA and benzodiazepine receptor respectively. There has only been one clinical study conducted on kava and sleep outcomes in people with insomnia, further clinical evidence is required to support this initial study. Given the number of trials conducted forkava in other conditions (i.e. anxiety and depression) and their reported beneficial effects on the central nervous system it is quite possible that kava could be a very important herb for rectifying sleep problems in people with insomnia [56-58]. Two clinical studies have been conducted on chamomile and sleep outcomes in insomnia. One study reported a positive result while the other reported no change in sleep outcomes in insomnia. These result are likely to be due to the dosage and administration duration, which need to be taken into account with this herb, much in the line as discussed above for valerian $[46,47]$.

There are a number of studies that have combined herbal medicines together to promote a synergistic effects to address as many of the different mechanisms associated with insomnia. To date all combinations of herbal medicines used to address insomnia have used the herb valerian. Herbal combinations of hops and valerian have been shown to improve sleep outcomes compared to valerian on its own [49]. This observed effect is likely to be caused by the additive effect of hops in the herbal combination; although the dosage of valerian is again below the therapeutic recommendations (Table 1). In one study the valerian/hops extract was found to act as a sleep aid by suppressing arousal via central adenosine mechanisms [59]. This suggests that components of the valerian/hops combination are adenosine agonists and is possibly the main reason as to why it promotes sleep-inducing effects [59]. In addition, valerian has been shown to increase GABA levels, that promote a sedative effective upon sleep.

Studies of longer duration (six weeks) have shown that valerian and kava are particularly beneficial in restoring insomnia [36,53]. These durations align more closely to the traditional prescribing rules of herbal medicine, that is paired too the severity and chronicity of conditions like insomnia [37]; with diseases existing for 12 months, traditionally requiring three months of herbal medicine treatment (37). For every year above and beyond the initial year, an additionally month is required
[37]. The time period of administration requires significant attention, as no study has extended beyond six weeks of treatment for any single or combination herb/s (Table 1). Future studies should be directed towards extending the time period over which herbal medicines are taken in people experiencing chronic insomnia. In addition, trials need to be designed to test the effectiveness of different herbal combinations in individuals with insomnia; considerations for leveraging off as many of the herbal actions should be taken into account to address the underlying pathology of insomnia.

\section{How do we study these medicines? What are the best} methods?

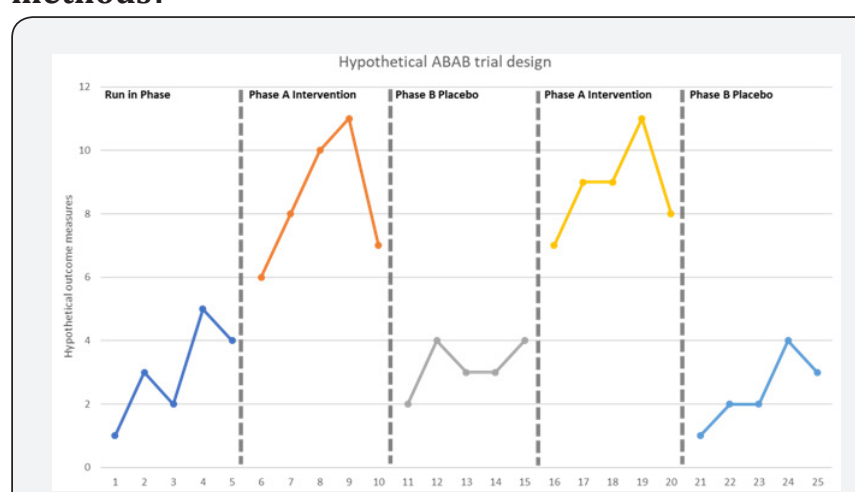

Figure 1: Hypothetical $A B A B$ n-of-1 trial design without washout period shown.

$\mathrm{N}$-of-1 trials and single case experimental designs are uniquely positioned to study the individual person and how they respond to medicines. $\mathrm{N}$-of- 1 methods involve repeated outcome measurements in an individual over time to draw conclusions specific to that individual. N-of-1 RCT design randomly allocates different time periods within an individual to treatment or control conditions, thereby extending group based RCTs to the individual level. $\mathrm{N}$-of-1 methodologies have been reported to provide the highest level of evidence for making individual treatment decisions [60]; furthermore, these methods also allow for accurate and reliable evaluation of health interventions [61]. It has been reported that $\mathrm{N}$-of- 1 trials and single RCTs with multiple crossovers are highly applicable to chronic conditions that require long-term treatment [62]. In N-of-1 trials there are control and treatment phases - where the participants in these trials are subjected to both phases. Trial designs typically consist of two control (denoted as A) and treatment (denoted as B) phases represented as $\mathrm{ABAB}$ or ABBA (hypothetical trial design is shown below in Figure 1); other treatment sequences may involve three or four control and treatment phases, denoted as $A B A B A B$ or ABBAABBA. Washout periods are an important consideration in $\mathrm{N}$-of- 1 trials as it might possibly influence the outcome measurements obtained in subsequent phases. Carryover effects resulting from insufficient washout will often tend to reduce observed differences between treatments and placebo-controlled phases. There are possible downsides of washout periods in that the participants are forced to spend some time completely off treatment, which might be undesirable 
for participants who already receive some benefit from the treatment phase. This raises the importance of therapeutic halflives, which can vary among individuals and in some instances are not well characterised, but if the half-life is short relative to the length of treatment, washout periods may not be applicable in the design of the study in this situation. Applying this model to the practice of herbal medicine may be a bit more complicated since herbs have many constituents that have unknown pharmacokinetic profiles and metabolic half-lives.

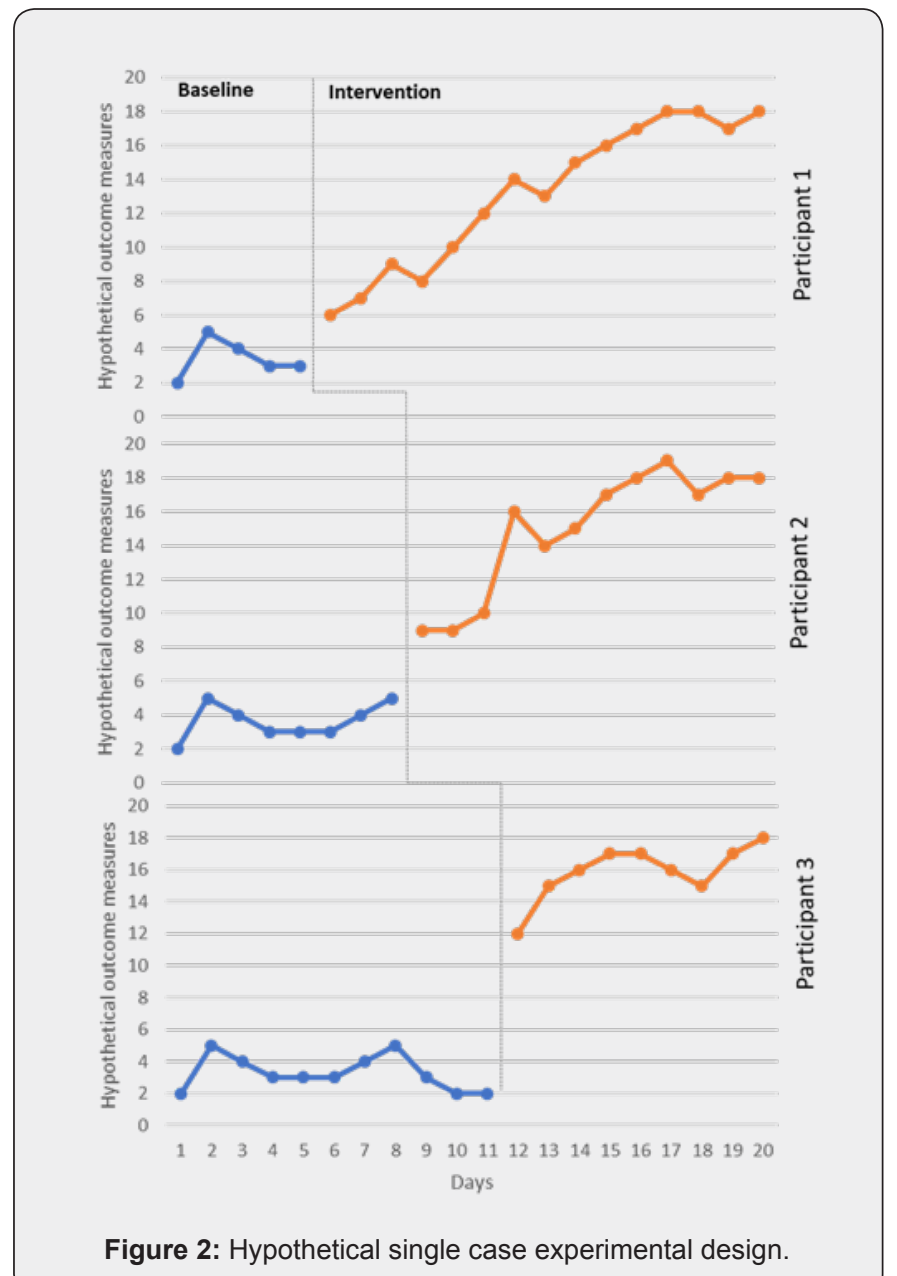

$\mathrm{N}$-of-1 trial methodologies have shown that herbal medicines provide beneficial effects in a range of different health conditions. Johnston and Mills (2004) published a review identifying the feasibility of $\mathrm{N}$-of- 1 trials to better evaluate the clinical and statistical significance of complementary and alternative therapies. There have been very few N-of-1 trials published in the area of herbal medicine. For example, N-of- 1 trials have shown that Ginkgo biloba has an effect on cognition in some individuals and not in others [63], highlighting the individual response to this particular herbal medicine. Traditional Chinese herbal decoctions have been reported to be beneficial for the respiratory condition bronchiectas is using N-of-trials [64]. Given the growth of personalised medicine these trials may be implemented where appropriate to provide valid findings on the effects of herbal medicines on chronic conditions at the individual level.

Single case experimental designs may provide an alternative to $\mathrm{N}$-of- 1 trials with repeated treatment and control phases (ABAB designs) to study the benefits of herbal medicines. There has been some scepticism about the clinical utility of randomised controlled trials, with renewed interest in SCEDs as a means to assess intervention outcomes [65]. The central goal of SCEDs is to determine whether a casual or functional relationship exists between a researchers-manipulated independent variable and a meaningful change in the dependent variable.

To our knowledge, there are no SCEDs with multiple baseline designs (MBD) that have been utilised to study the benefits of herbal medicines in any chronic diseases. MBD have a long history in psychological research, where an intervention is provided at different baseline times [66-68]. This model is highly relevant and more efficient than $\mathrm{N}$-of- 1 trials as we do not need to consider the metabolic half-life of these medicines in the design of these trials as we move from baseline phase to intervention phase with no return to baseline; or requirement of washout periods. During the baseline phase assessments are made, with at least five data points for participant number one required and an additional 3 data points required for participants two and six data points for participant three (Sample size $n=3$ ) [69]. After the baseline phase the intervention is introduced to each participant on day 6, 9 and 12 respectively for the above mentioned baseline periods. A model showing a hypothetical change in data between the baseline and intervention phase is shown below in Figure 2. When the intervention is applied to the first participant the other two participants are still in the baseline period, and we would expect to see a change in participant one if the intervention is effective and no change too the other participants as they are still in the baseline phase (as shown in Figure 2). Next, the intervention is applied to the second participants while the third participant is in the baseline phase; and observation are continued to be made in participant number one, receiving the intervention. Finally, the third participant receives the intervention phase with observation recorded across all three participants. At this point we can conclude that there is a functional relationship between the independent and dependent variable as each participant received the intervention there was significant changes from the baseline phase. We can also conclude that there are no other external factor/s that are contributing to this relationship observed.

\section{References}

1. Adams RJ, Appleton SL, Taylor AW, Gill TK, Lang C, et al. (2017) Sleep health of Australian adults in 2016: results of the 2016 Sleep Health Foundation national survey. Sleep Health 3(1): 35-42.

2. Sanford LD, Suchecki D, Meerlo P (2015) Stress, arousal, and sleep. Current Topics in Behavioral Neurosciences 25: 379-410.

3. Ohayon MM, Reynolds CF (2009) Epidemiological and clinical relevance of insomnia diagnosis algorithms according to the DSM-IV and the International Classification of Sleep Disorders (ICSD). Sleep Med 10(9): 952-960. 
4. Saddichha S (2010) Diagnosis and treatment of chronic insomnia. Ann Indian Acad Neurol 13(2): 94-102.

5. Harvey AG, Belanger L, Talbot L, Eidelman P, Beaulieu-Bonneau S, et al. (2014) Comparative efficacy of behavior therapy, cognitive therapy, and cognitive behavior therapy for chronic insomnia: a randomized controlled trial. J Consult Clin Psychol 82(4): 670-683.

6. Kay-Stacey M, Attarian H (2016) Advances in the management of chronic insomnia. BMJ 354: i2123.

7. Hirshkowitz M, Whiton K, Albert SM, Alessi C, Bruni O, et al. (2015) National Sleep Foundation's updated sleep duration recommendations: final report. Sleep Health 1(4): 233-243.

8. Cronlein T (2016) Insomnia and obesity. Curr Opin Psychiatry 29(6): 409-412.

9. Cunnington D, Junge MF, Fernando AT (2013) Insomnia: prevalence, consequences and effective treatment. Med J Aust 199(8): S36-S40.

10. Dong L, Soehner AM, Belanger L, Morin CM, Harvey AG (2018) Treatment Agreement, Adherence, and Outcome in Cognitive Behavioral Treatments for Insomnia. J Consult Clin Psychol 86(3): 294299.

11. Hata T, Kanazawa T, Hamada T, Nishihara M, Bush AI, et al. (2018) What can predict and prevent the long-term use of benzodiazepines? J Psychiatr Res 97: 94-100.

12. Morin CM, Culbert JP, Schwartz SM (1994) Nonpharmacological interventions for insomnia: a meta-analysis of treatment efficacy. Am J Psychiatry 151(8): 1172-1180.

13. Smith MT, Perlis ML, Park A, Smith MS, Pennington J, et al. (2002) Comparative meta-analysis of pharmacotherapy and behavior therapy for persistent insomnia. Am J Psychiatry 159(1): 5-11.

14. Murtagh DR, Greenwood KM (1995) Identifying effective psychological treatments for insomnia: a meta-analysis. J Consult Clin Psychol 63(1): 79-89.

15. Arnedt JT, Cuddihy L, Swanson LM, Pickett S, Aikens J et al. (2013) Randomized controlled trial of telephone-delivered cognitive behavioral therapy for chronic insomnia. Sleep 36(3): 353-362.

16. Pagel JF (2005) Medications and their effects on sleep. Prim Care 32(2): 491-509.

17. Morin CM, Edinger JD, Krystal AD, Buysse DJ, Beaulieu-Bonneau S, et al. (2016) Sequential psychological and pharmacological therapies for comorbid and primary insomnia: study protocol for a randomized controlled trial. Trials 17(1): 118.

18. Griffin CE $3^{\text {rd }}$, Kaye AM, Bueno FR, Kaye AD (2013) Benzodiazepine pharmacology and central nervous system-mediated effects. Ochsner J 13(2): 214-223.

19. Kelly MD, Smith A, Banks G, Wingrove P, Whiting PW, et al. (2002) Role of the histidine residue at position 105 in the human alpha 5 containing GABA(A) receptor on the affinity and efficacy of benzodiazepine site ligands. Br J Pharmacol 135(1): 248-256.

20. Nowell PD, Mazumdar S, Buysse DJ, Dew MA, Reynolds CF $3^{\text {rd }}$ (1997) Benzodiazepines and zolpidem for chronic insomnia: a meta-analysis of treatment efficacy. JAMA 278(24): 2170-2177.

21. Perlis ML, Smith MT, Orff H, Enright T, Nowakowski S, et al. (2004) The effects of modafinil and cognitive behavior therapy on sleep continuity in patients with primary insomnia. Sleep 27(4): 715-725.

22. Roehrs TA, Randall S, Harris E, Maan R, Roth T (2012) Twelve months of nightly zolpidem does not lead to rebound insomnia or withdrawal symptoms: a prospective placebo-controlled study. J Psychopharmacol 26(8): 1088-1095.
23. Krystal AD, Erman M, Zammit GK, Soubrane C, Roth T (2008) Long-term efficacy and safety of zolpidem extended-release $12.5 \mathrm{mg}$, administered 3 to 7 nights per week for 24 weeks, in patients with chronic primary insomnia: a 6-month, randomized, double-blind, placebo-controlled, parallel-group, multicenter study. Sleep 31(1): 79-90.

24. Pagel JF (2001) Medication effects on sleep. Dental clinics of North America 45(4): 855-865.

25. Leach MJ, Page AT (2015) Herbal medicine for insomnia: A systematic review and meta- analysis. Sleep Med Rev 24: 1-12.

26. Romero K, Goparaju B, Russo K, Westover MB, Bianchi MT (2017) Alternative remedies for insomnia: a proposed method for personalized therapeutic trials. Nat Sci Sleep 9: 97-108.

27. Sarris J, Panossian A, Schweitzer I, Stough C, Scholey A (2011) Herbal medicine for depression, anxiety and insomnia: a review of psychopharmacologyand clinical evidence. Eur Neuropsychopharmacol 21(12): 841-860.

28. Nunes A, Sousa M (2011) Use of valerian in anxiety and sleep disorders: what is the best evidence?. Acta Med Port 24 Suppl 4: 961-966.

29. Balderer G, Borbély A (1985) Effect of valerian on human sleep. Psychopharmacology 87(4): 406-409.

30. Donath F, Quispe S, Diefenbach K, Maurer A, Fietze I, et al. (2000) Critical Evaluation of the Effect of Valerian Extract on Sleep Structure and Sleep Quality. Pharmacopsychiatry 33(2): 47-53.

31. Oxman AD, Flottorp S, Havelsrud K, Fretheim A, Odgaard-Jensen J, et al. (2007) A televised, web-based randomised trial of an herbal remedy (valerian) for insomnia. PloS one 2(10): e1040.

32. Coxeter PD, Schluter PJ, Eastwood HL, Nikles CJ, Glasziou PP (2003) Valerian does not appear to reduce symptoms for patients with chronic insomnia in general practice using a series of randomised n-of- 1 trials. Complement Ther Med 11(4): 215-222.

33. Diaper A, Hindmarch I (2004) A double-blind, placebo-controlled investigation of the effects of two doses of a valerian preparation on the sleep, cognitive and psychomotor function of sleep-disturbed older adults. Phytother Res 18(10): 831-836.

34. Taibi DM, Vitiello MV, Barsness S, Elmer GW, Anderson GD, et al. (2009) A randomized clinical trial of valerian fails to improve self-reported, polysomnographic, and actigraphic sleep in older women with insomnia. Sleep Med 10(3): 319-328.

35. Amy E (1995) Medicinal Plants of the Pacific West (Book Review). p. 233.

36. Ziegler G, Ploch M, Miettinen-Baumann A, Collet W (2002) Efficacy and tolerability of valerian extract LI 156 compared with oxazepam in the treatment of non-organic insomnia--a randomized, double-blind, comparative clinical study. Eur J Med Res 7(11): 480-486.

37. Bone K, Mills S (2013) Principles and Practice of Phytotherapy Modern Herbal Medicine: Churchill Livingstone, Elsevier p. 1051.

38. Grieve M (1974) A modern herbal : the medicinal, culinary, cosmetic, and economic properties, cultivation, and folklore of herbs, grasses, fungi, shrubs, and trees with all their modern scientific uses / by M. Grieve ; edited and introduced by C. F. Leyel. Hafner Press, New York, USA.

39. Taavoni S, Ekbatani N, Kashaniyan M, Haghani H (2011) Effect of valerian on sleep quality in postmenopausal women: a randomized placebo-controlled clinical trial. Menopause 18(9): 951-955.

40. Teschke R, Sarris J, Schweitzer I (2012) Kava hepatotoxicity in traditional and modern use: the presumed Pacific kava paradox hypothesis revisited. Br J Clin Pharmacol 73(2): 170-174. 
41. Shi Y, Dong JW, Zhao JH, Tang LN, Zhang JJ (2014) Herbal Insomnia Medications that Target GABAergic Systems: A Review of the Psychopharmacological Evidence. Curr Neuropharmacol 12(3): 289302.

42. Gottesmann C (2002) GABA mechanisms and sleep. Neuroscience 111(2): 231-239.

43. Wheatley D (2005) Medicinal plants for insomnia: a review of their pharmacology, efficacy and tolerability. Journal of psychopharmacology (Oxford, England) 19(4): 414-421.

44. Lehrl S (2004) Clinical efficacy of kava extract WS ® 1490 in sleep disturbances associated with anxiety disorders: Results of a multicenter, randomized, placebo-controlled, double-blind clinical trial. J Affect Disord 78(2): 101-110.

45. Srivastava JK, Shankar E, Gupta S (2010) Chamomile: A herbal medicine of the past with bright future. Mol Med Rep 3(6): 895-901.

46. Adib-Hajbaghery M, Mousavi SN (2017) The effects of chamomile extract on sleep quality among elderly people: A clinical trial. Complementary Therapies Med 35: 109-114.

47. Zick SM, Wright BD, Sen A, Arnedt JT (2011) Preliminary examination of the efficacy and safety of a standardized chamomile extract for chronic primary insomnia: a randomized placebo-controlled pilot study. BMC Complement Altern Med 11: 78.

48. Salter S, Brownie S (2010) Treating primary insomnia - the efficacy of valerian and hops. Australian Family Physician 39(6): 433-437.

49. Morin CM, Koetter U, Bastien C, Ware JC, Wooten V (2005) Valerianhops combination and diphenhydramine for treating insomnia: a randomized placebo-controlled clinical trial. Sleep 28(11): 1465-1471.

50. Koetter U, Schrader E, Kaufeler R, Brattstrom A (2007) A randomized, double blind, placebo-controlled, prospective clinical study to demonstrate clinical efficacy of a fixed valerian hops extract combination (Ze 91019) in patients suffering from non-organic sleep disorder. Phytother Res 21(9): 847-851.

51. Maroo N, Hazra A, Das T (2013) Efficacy and safety of a polyherbal sedative-hypnotic formulation NSF-3 in primary insomnia in comparison to zolpidem: a randomized controlled trial. Indian J pharmacol 45(1): 34-39.

52. Wheatley D (2001) Kava and valerian in the treatment of stressinduced insomnia. Phytother Res 15(6): 549-551.

53. Wheatley D (2001) Stress-induced insomnia treated with kava and valerian: singly and in combination. Human Psychopharmacology 16(4): 353-356.

54. Jacobs BP, Bent S, Tice JA, Blackwell T, Cummings SR (2005) An internetbased randomized, placebo-controlled trial of kava and valerian for anxiety and insomnia. Medicine 84(4): 197-207.
55. Lehrl S (2004) Clinical efficacy of kava extract WS 1490 in sleep disturbances associated with anxiety disorders. Results of a multicenter, randomized, placebo-controlled, double-blind clinical trial. J Affect Disord 78(2): 101-110.

56. Connor KM, Payne V, Davidson JR (2006) Kava in generalized anxiety disorder: three placebo-controlled trials. Int Clin Psychopharmacol 21(5): 249-253.

57. Sarris J, Kavanagh DJ, Byrne G, Bone KM, Adams J, et al. (2009) The Kava Anxiety Depression Spectrum Study (KADSS): a randomized, placebo-controlled crossover trial using an aqueous extract of Piper methysticum. Psychopharmacology 205(3): 399-407.

58. Sarris J, Stough C, Bousman CA, Wahid ZT, Murray G, et al. (2013) Kava in the treatment of generalized anxiety disorder: a doubleblind, randomized, placebo-controlled study. Journal of clinical psychopharmacology 33(5): 643-648.

59. Schellenberg R, Sauer S, Abourashed EA, Koetter U, Brattstrom A (2004) The fixed combination of valerian and hops (Ze91019) acts via a central adenosine mechanism. Planta Med 70(7): 594-597.

60. Ocebm Levels of Evidence Working G. Oxford Centre for EvidenceBased Medicine 2011 Levels of Evidence - Traduction française. 2012.

61. Nikles CJ, Clavarino AM, Del Mar CB (2005) Using n-of-1 trials as a clinical tool to improve prescribing. Br J Gen Pract 55(512): 175.

62. Mahon J, Feagan B, Laupacis A (1995) Ethics of n-of-1 trials. p. 989.

63. Canter PH, Ernst E (2003) Multiple $n=1$ trials in the identification of responders and non-responders to the cognitive effects of Ginkgo biloba. Int J Clin Pharmacol Ther 41(8): 354-357.

64. Huang H, Yang P, Xue J, Tang J, Ding L, et al. (2014) Evaluating the Individualized Treatment of Traditional Chinese Medicine: A Pilot Study of N-of-1 Trials. Evid Based Complement Alternat Med 2014: 148730.

65. Smith JD (2012) Single-case experimental designs: a systematic review of published research and current standards. Psychol Methods 17(4): 510-550.

66. Fechner GT, Howes DH, Boring EG (1966) Elements of psychophysics. Translated by: Helmut E Adler Edited by Davis H. Howes, Edwin G. Boring ; with an introd. by Edwin G. Boring. Holt, Rinehart and Winston, New York, USA.

67. Watson JB (1925) Behaviorism. Norton, New York, USA.

68. Skinner BF (1938) The behaviour of organisms. Appleton-CenturyCrofts, New York, USA.

69. Hser YI, Shen H, Chou CP, Messer SC, Anglin MD (2001) Analytic approaches for assessing long-term treatment effects. Examples of empirical applications and findings. Evaluation Review 25(2): 233262.

Your next submission with Juniper Publishers
will reach you the below assets
- Quality Editorial service
- Swift Peer Review
- Reprints availability
- E-prints Service
- Manuscript Podcast for convenient understanding
- Global attainment for your research
- Manuscript accessibility in different formats
( Pdf, E-pub, Full Text, Audio)
- Unceasing customer service
Track the below URL for one-step submission
https://juniperpublishers.com/online-submission.php

